\title{
Reform Trend of Investor-State Dispute Settlement in International Investment
}

\author{
Bowen Liu ${ }^{1}$ \\ ${ }^{1}$ China Institute of Boundary and Ocean Studies, Wuhan University, Wuhan, China \\ Correspondence: Bowen Liu, China Institute of Boundary and Ocean Studies, Wuhan University, Wuchang \\ District, Wuhan, Hubei, China. E-mail: liubowenlaw@163.com
}

Received: January 15, 2022

doi:10.20849/ajsss.v7i2.1006
Accepted: February 10, 2022

Online Published: February 27, 2022

URL: https://doi.org/10.20849/ajsss.v7i2.1006

\begin{abstract}
The reform of Investor-State Dispute Settlement (hereafter "ISDS") is a bellwether for the reform of the international investment dispute settlement mechanism, this paper about the ISDS mechanism reform finds the root cause of ISDS mechanism reform comes from the national sovereignty and the interests of the investors under the conflict of "crisis of legitimacy" Based on the" legitimacy" crisis, the ISDS mechanism has many problems. In this context, countries have started to reform the ISDS mechanism in order to solve the corresponding problems. These reform measures have three typical trends, Facing the three trends of ISDS mechanism reform, Chinese scholars put forward countermeasures from various angles, but fundamentally China should recognize its own position in international investment, be realistic and adopt a flexible way to deal with ISDS mechanism reform, and try best to contribute to ISDS mechanism reform.
\end{abstract}

Keywords: international investment, ISDS, reform

\section{Reasons for the Reform of Investor-State Dispute Settlement Mechanism}

Investor-state dispute settlement exists not only in multilateral system represented by International Center for Settlement of Investment Disputes (ICSID), but also in regional and bilateral agreements. It includes all the institutional arrangements, institutional existence and dispute settlement practices for resolving disputes between foreign private investors and the host country where they invest. The main manifestation of this mechanism is arbitration. This mechanism has promoted the development of international investment and made outstanding contributions to the legalization process in the field of international investment law. However, with the increase of the number of international investment arbitration cases, investor-state dispute settlement also exposed a series of problems, such as the consistency of awards, transparency is not high. There was not much controversy. The author thinks that the fundamental cause of ISDS reform should be based on the historical development of international investment. The fundamental contradiction lies in the conflict and contradiction between the interests of state sovereignty and investors.

It is generally believed that the lack of consistency in ISDS rulings, the lack of transparency in procedures and other issues have caused damage to the sovereign rights of the host country, that is, the authorized party has caused damage to the authorized party, resulting in the "legitimacy crisis". (Note 1) The procedural problems of ISDS mechanism mainly focus on the transparency of arbitration procedure, the harsh conditions of host country counterclaim, the imperfect appeal mechanism and cancellation mechanism of the first award, and the unitary opening of the procedure. The substantive aspects focus on the inconsistency of the award, the "investor bias of the chief arbitrator" in the selection of arbitrators, the arbitrary interpretation and application of rules, and the neglect of the public interests of the host country. (Note 2) In addition, ISDS mechanism also has the problem of "parallel procedures" resulting in the waste of judicial resources and increased risk of inconsistent rulings. In addition to the above specific legal issues, it should also be recognized that after the Second World War, the western developed countries represented by the United States recovered quickly and gradually produced a large amount of "excess" capital. Driven by this interest, the home country of investors actually acted as the "salesman" of investors. Developed countries represented by the United States, Germany began to sign corresponding investment treaties with other nations. In the process, the first overseas investment insurance system emerged. The insurance provides that in the event of a special event such as political risk, the investor has the right to apply to the insurance agency for a claim, then, insurance institutions obtain subrogation rights from overseas investors against the host country. This means private subjects began to challenge sovereign states, which making international investment treaties 
appear features of "private law". In order to protect their own investment better, western developed countries, as the makers of international investment rules, pushed for the establishment of rules giving investors the right of direct appeal, and ISDS mechanism came into being. At that time, most of the investment importing countries were developing countries, which had a strong demand for economic development and a low degree of economic development after the war. ISDS mechanism not only enhanced investors' confidence in investment, but also met the demand of capital importing countries for economic development. But with the development of world economy, the economy of developing countries have made great progress, the role of international investment of some countries also began to shift from pure importer for exporting countries, developed countries accused cases increased, but the ISDS mechanism is increasingly inclined to protect investors and cannot be well balance the interests of the host country, thus incurred "crisis of legitimacy". This has become the fundamental reason for the reform of ISDS mechanism.

\section{Direction of Investor-State Dispute Settlement Reform}

Based on the above reasons, there are some practices in the reform of ISDS mechanism both at the national level and at the international community level. For example, on the issue of arbitration transparency, The United Nations Commission on International Trade Law (UNCITRAL) adopted the Rules on Transparency of Invested-State Treaty-based Arbitration on July 11, 2013.In addition, the Trans-Atlantic Trade and Investment Partnership agreement (TTIP) promoted by EU and its members, the 2012 BIT model of the United States and the Trans-Pacific Relations Agreement (TPP) promoted by the United States show that the ISDS reform carried out by EU and the United States represents two different but extremely important directions in the reform of ISDS mechanism. It is not difficult to see from the above research that the reform of ISDS mechanism has shown a trend of diversified development. But in general, the reform of ISDS mechanism mainly has three directions:

\subsection{Reformists Represented by the United States and Japan}

The reform measures adopted by the us and Japan for ISDS mechanism are mainly reflected in the us 2012BIT model, trans-pacific partnership agreement (TPP) and comprehensive and progressive trans-pacific partnership agreement (CPTPP).These files are all pay attention to the detailed rules for the ISDS arbitration clause, emphasize to submit to arbitration, the rights and obligations of both sides, and the condition of the choice of the arbitrator shall be strict rules, compared with TPP, CPTPP also allow participants to "freeze" clause and the official way further restrict ISDS mechanism to be able to submit the investment disputes arbitration. These measures do not touch on the nature of ISDS arbitration. (Note 3)

\subsection{Reformists Represented by the European Union}

The Trans-Atlantic Trade and Investment Partnership Agreement (TTIP) and Comprehensive Economic and Trade Agreement (CETA) promoted by THE EU reflect the EU's reflection on the effect of ISDS mechanism at the present stage. The EU has adopted the following major reform measures to address the existing problems of ISDS mechanism: Strengthening the powers of parties to investment agreements on treaty interpretation, adopting the FET standard closed list approach to regulate the scope of cases under ISDS arbitration, establishing joint commissions and permanent Investment courts to address the excessive scope of disputes and lack of appellate remedies under traditional ISDS mechanisms, This approach is characterized as quasi-judicial or judicial in that it introduces full proceedings and completely overturns the arbitral nature of ISDS. (Note 4)

\subsection{Exclusionists Represented by Latin American Countries}

Due to complex reasons such as the huge impact of cases in ICSID on national sovereign interests and the "Argentine crisis", Latin American countries represented by Argentina, Bolivia, Venezuela and Brazil began to boycott ISDS mechanism, and some of them directly declared to withdraw from ICSID convention. Some will terminate the ICSID convention at some point in the future, and have removed the ISDS provisions from investment agreements with other countries in favor of inter-state dispute settlement. Those countries that are completely opposed to the ISDS and insist on a return to inter-state dispute settlement are regarded as rejectionist. The trend and Argentina's foreign minister, carver is put forward in 1868 "adhere to the jurisdiction of the domestic law, against the abuse of diplomatic protection advocates", its essence is in the field of international investment dispute settlement against the idea of "super national treatment", belong to "calvo doctrine" in the field of international investment dispute settlement of resurrection, is back in the field of investment dispute settlement. (Note 5)

There are various evaluations on the above reform measures, but the evaluation of TPP model represented by the United States and TIPP model proposed by the European Union is roughly the same, that is, TPP model has solved the problems existing in ISDS mechanism to a certain extent by limiting the initiation of arbitration, improving the transparency of arbitration, and strictly selecting and appointing arbitrators. But it does not touch on the "crisis of legitimacy" in which ISDS limits the host country's regulatory power. Although the ICS mechanism designed by 
the EU TTIP is the most ideal model to solve the "legitimacy crisis" of ISDS, its details still need a lot of research and practice, and it will take a long time for it to be accepted by the international community. Meanwhile, this initiative is also opposed by many scholars from countries supporting ISDS mechanism. About the exit mechanism of ISDS to SSDS mechanisms "carver" national measures, evaluate the differences, some scholars think that the country's "return" to using the method of building political authority limit international judicial institutions behavior, help build a more appropriate international investment dispute settlement mechanism,, but some scholars will be completely negative attitude to this, Such a huge contrast may be caused by different scholars' different understandings of corresponding countries due to different connotation and evaluation criteria of "Cavorism". However, there is no obvious dispute about the practicality of the TPP model represented by the United States at present. (Note 6)

\section{China's Response to the Trend of Investor-State Dispute Settlement Reform}

The reform of ISDS mechanism is in full force, and many scholars have put forward suggestions on how to face this reform in China. For example, in terms of the specific overall setting of ISDS, the specific provisions of the international investment arbitration exception clause and the arbitration procedure rules of investment treaties should be improved to meet the corresponding needs of dispute settlement. In terms of promoting China's international investment protection, China should actively promote the negotiation of investment treaties between China and the United States and between China and the European Union, and put forward a reform plan of ISDS mechanism with Chinese characteristics that balances the maintenance of sovereignty security and improvement of ISDS relief procedures. Facing the reform tide of ISDS mechanism, China should actively absorb the experience and lessons of the above three main reform directions, and take measures in accordance with its own situation. In the short term, the specific provisions of the dispute settlement mechanism, especially the ISDS mechanism, in the BIT model should be improved by adopting the path of the US and Japan, so as to control the scope of ISDS arbitration and avoid the corresponding risks. Countries that reject ISDS arbitration mechanism can be treated differently in the negotiations and other feasible modes can be explored. In the medium term, China can rely on its own strategy or relevant international organizations, such as the Asian Infrastructure Investment Bank, to establish or improve a dispute settlement mechanism that reflects China's voice and is suitable for win-win cooperation and common development between China and its neighboring countries. In the long run, China, the EU, Canada and other countries should actively participate in the reform of international investment disputes under the framework of UNCITRAL, prudently design and actively promote the multilateral permanent court plus appellate body model, and gradually solve the problems existing in the current ISDS mechanism.

In the region of the one blet and one road initiative (BRI), build the regional investment dispute settlement mechanism should fully consider the facts that surrounding countries do not have a high level of development and the characteristics of investment disputes and value. In terms of domestic of domestic investment and legal environment, China should follow the pilot and cultivate a foreign-related legal talent; At the international level, China should fully respect other countries' willingness to ensure the diversity of dispute settlement mechanism, and relying on the investment Banks and other institutions set up multilateral dispute settlement mechanism in the region of BRI. At the same time, China shoulders great responsibility in pushing the process of the reform of ISDS, China should make the positive contribution for the world with its own experience in dealing with the international investment dispute settlement, make China's voice heard in ISDS reform. (Note 7) Also, China should integrate more elements of Chinese culture, mainly mediation, and actively absorb the results of ISDS mechanism reform, focusing on the establishment of appeal mechanism, arbitrator selection and transparency of the relevant provisions. Meanwhile, attention should be paid to the establishment of the dispute prevention system. The establishment of corresponding dispute prevention measures is more advantageous in economic aspects than the settlement of disputes after the event, and can overcome the shortcomings of the existing ISDS mechanism. The dispute prevention mechanism can be carried out by setting up special departments and carrying out multilateral cooperation on investment facilitation.

As for the dispute settlement rules of CHINA-ASEAN Free Trade Area, China should consider regulating the scope of application of investment arbitration, improving the arbitrator system, and considering the establishment of a permanent arbitration tribunal. Facing the ISDS reform tide, the most important principle is to recognize the changes in the role of international investment of our country, from set out actually, and considerate international investment dispute settlement mechanism reform measures whether comply its national conditions and can be accept by the relative countries. China should, with pragmatic attitude, take corresponding measures, and gradually increase its own voice in international investment dispute settlement mechanism reform.

\section{Conclusion}

As the most important part of the dispute settlement mechanism in bilateral investment treaties, the reform direction of ISDS mechanism represents the reform trend of the dispute settlement mechanism in bilateral 
investment treaties. Because of the "legitimacy" crisis, the reform of ISDS has become a practical need in the field of international investment dispute settlement. Countries adopt different ISDS mechanism reform measures based on their role in the field of international investment, so the ISDS reform has the characteristics of diversification, but its essence can be roughly divided into "reformists" represented by the United States, "revolutionaries" led by the European Union and "rejectionist" led by Latin American countries. How to face the reform of ISDS mechanism, the academic circle has put forward a lot of suggestions, in the final analysis, it is necessary to recognize China's role transformation in the field of international investment, flexibly and pragmatically adopt appropriate ISDS provisions with countries with different positions, and actively participate in the reform of ISDS worldwide.

\section{References}

Deng, T.-T. (2019). The EU multilateral investment court: motivation, feasibility and challenge. Journal of China Southern University (Social Sciences Edition), 25(4), 62-72.

Han, X.-L. (2014). On the Resurrection of Calvo Doctrine -- from the perspective of investor-state dispute settlement. Modern Law, 36(1), 121-135.

Liang, Y. (2018). Research on the Reform of International Investment Arbitration Mechanism and China's Countermeasures. Journal of Xiamen University (Philosophy and Social Sciences), (3), 160-172.

Liu, Y. (2018). Review of Overseas Research on investor-state dispute settlement. Social Sciences in Foreign Countries, (6), 13-24.

Susan, D. F. (2005). The Legitimacy Crisis in Investment Treaty Arbitration: Privatizing Public International Law Through Inconsistent Decisions. Fordham Law Review, 73(4), 1521-1625.

Wang, X.-X. (2020). Construction of investment dispute settlement mechanism under the belt and Road Initiative. Northeast Asia Forum, 29(4), 15-26, 127.

Wang, Y.-Z. (2019). Multiple models of international investment dispute settlement mechanism reform and China's choice. Journal of Central South University (Social Science), 25(4), 73-82.

Zhu, M.-X. (2018). The innovation of investor-state dispute Settlement mechanism and the "return" of state. International Law Studies, (4), 16-30.

\section{Notes}

Note 1. Susan D. Franck. The Legitimacy Crisis in Investment Treaty Arbitration: Privatizing Public International Law through Inconsistent Decisions. Fordham Law Review, Vol. 73, No. 4, 2005, pp. 1521-1625.

Note 2. Liu Ying. Review of Overseas Research on investor-state dispute settlement. Social Sciences in Foreign Countries, 2018(6), 13-24.

Note 3. Liang Yong. Research on the Reform of International Investment Arbitration Mechanism and Chin's Countermeasures. Journal of Xiamen University (Philosophy and Social Sciences), 2018(3), 160-172.

Note 4. Deng Tingting, The EU multilateral investment court: motivation, feasibility and challenge. Journal of China southern university (social sciences edition), 2019, 25(4), 62-720.

Note 5. Han Xiuli, On the Resurrection of Calvo Doctrine - from the perspective of investor-state dispute settlement. Modern law, 2014, 36(1), 121-135.

Note 6. Wang Yanzhi. Multiple models of international investment dispute settlement mechanism reform and China's choice. Journal of central south university (social science), 2019, 25(4), 73-82.

Note 7. Wang Xiuxiang. Construction of investment dispute Settlement mechanism under the Belt and Road Initiative. Northeast Asia forum, 2020, 29(4), 15-26, 127.

\section{Copyrights}

Copyright for this article is retained by the author(s), with first publication rights granted to the journal.

This is an open-access article distributed under the terms and conditions of the Creative Commons Attribution license (http://creativecommons.org/licenses/by/4.0/). 